\title{
Frequency of visits and examinations in the Public Dental Service in Finland - a retrospective analysis, 2001-2013
}

\author{
Jari Linden ${ }^{1 *}$, Kim Josefsson ${ }^{2}$ and Eeva Widström ${ }^{2,3}$
}

\begin{abstract}
Background: This study aimed to investigate longitudinally examination and visiting patterns in the Finnish Public Dental Service (PDS) and to relate these to patients' treatment needs and international recommendations on examination intervals.

Methods: Data on patients and their dental visits in the period 2001-2013 were collected from five municipal PDS-units serving a total population of 320,000 inhabitants and using the same database system. Ethical approval was given by the National Institute for Health and Welfare (THL) and permissions to use local data by the directors of health services in each unit. For each year, the numbers of visitors, those examined and those in need of basic periodontal or caries treatment (CPI $>2$ and $\mathrm{D}+\mathrm{d}>0$ ) were calculated separately for young people ( $<18$ years), the working-aged (18-64 years) and the elderly (65+ years). Each individual's examination and visiting intervals were counted. Multilevel modelling was used to study probabilities of being examined or in need of treatment and differences in examination and visiting intervals between groups and over time.
\end{abstract}

Results: From 2001 to 2013, the number of visitors increased by 39.3\% and the working-aged became the biggest patient group rather than the young. Compared with adults, the young were five times more likely to be examined $(\mathrm{OR}=4.97)$ and three times less likely to require treatment $(\mathrm{OR}=0.31)$. On average, $37 \%$ of the young, $73 \%$ of the working-aged and $63 \%$ of the elderly needed basic treatment. Multi-level analysis showed that the young had the shortest examination intervals and the working aged the longest ( 0.50 years longer). Most examination intervals of the young and the elderly were 1 year $(65.2-77.0 \%)$, but only half (49.5\%) of the working-aged were re-examined within 1 year. Over time, the examination intervals increased slightly in all groups. Most visiting intervals remained at 1 year.

Conclusion: Young patients had mostly annual or biannual examinations, in line with recommendations. The examination intervals of working aged adults were considerably longer, and more of them needed treatment. The share of elderly among visitors remained low. The PDS seems to have access barriers for adults.

Keywords: Register study, Examination intervals, Treatment need, Visiting interval, Public dental service

\footnotetext{
* Correspondence: jari.linden@lohja.fi

'Public Dental Service Lohja, Helsinki, Finland

Full list of author information is available at the end of the article
} 


\section{Background}

Dental and oral diseases affect all population groups and are difficult to recognise for lay persons. Thus, all people from young to old are advised to visit dentists (or dental hygienists) regularly. Besides ease of access, the use of dental services depends on financial and practical resources and cultural traditions. In the literature, the most commonly recommended revisiting period in dental care is 6 months [1]. There is little evidence supporting the recommendation, but dental professionals are convinced that frequent examinations allow disease to be detected and treated in time and preventive interventions to be delivered [2]. A clinical guideline in the UK recommends that the longest period between examinations for both children and adults should be 12 months; for adults maintaining good oral health and appropriate home care habits, this may be extended to 24 months [2]. The American and Irish Dental Associations recommend dental visits at least once a year to get a routine examination and cleaning [3, 4]. Commercial companies also recommend regular dental visits even for those who take excellent care of their teeth and gums at home - twice a year or more often, or just once a year [5].

In some countries the Medical Card dental schemes (Ireland) and public dental insurances reimburse (e.g. Sweden and Finland) an oral examination once a year.

In Finland, oral health care is delivered by the Public Dental Service (PDS) and private sector dentists. In 1972, the Primary Health Care Act obliged municipalities to organise and provide several types of primary health services to their inhabitants. In oral health care, the young were prioritised: annual examinations, all necessary care including preventive were to be offered free to all the young, everywhere in the country. Adults were to use private services and pay for them. Since the 1980s, adults were gradually given access to subsidised dental services in the PDS, starting with the youngest age groups. In parallel, the same adults were included in an evolving reimbursement scheme of private dental care by the National Health Insurance (NHI). Finally in 2002, those born before 1956 were also granted access to the PDS or to NHIreimbursed private dental care [6].

Adults' oral health has been monitored in three large national clinical (epidemiological) studies in 1980, 2000 and 2011 [7-9]. Rough statistics on the use of services, work force, costs and children's oral health have been collected in the PDS since its start [10]. However, these data have not been very useful for evaluation or management in the PDS [11]. Along with improved data collection since the late 90's, the performance of the public oral health care provision system can be studied more in detail. This is needed in the current tough economic and financial situation in Finland.
The aim of this study was to investigate examination intervals and dental visiting patterns in the PDS using register data in a longitudinal setting in 2001-2013, largely reflecting changes in coverage of adult services in the PDS. Additional aims were to study how examinations and treatment needs tallied, whether examination intervals changed during a longer period and how examination intervals accorded with recommendations in other countries.

\section{Methods}

Five PDS units in Southern Finland that use a specific electronic patient registration system (WinHit), were asked to participate in the study. Ethical approval was given by the National Institute for Health and Welfare (THL) and permission to use the local data by the directors of health services in each PDS unit. In 2001, the number of inhabitants in these PDS units' catchment areas was 271,301 and in $2013320,055(+15.2 \%)$ persons. The smallest unit had 25,679 and the biggest 182,072 inhabitants [12].

Using personal unique identifiers, the numbers of patients $(n=295,521)$, their dental visits $(n=3,281,300)$, examinations $(n=702,662)$, and treatment need in the years 2001-2013 were retrospectively collected from the municipal databases. Individual sequence numbers were created to replace all personal identifiers. For each year, the numbers of all patients that have at least one visit to the PDS during that year, those who have visited and been examined and among the examined, those in need of basic periodontal or caries treatment (CPI $>2, D+$ $\mathrm{d}>0$ ) were [13] calculated. Each individual's visits and examinations were separately grouped by year and the time (in years) between visiting years and examination years was counted. All these numbers were counted separately for the young ( $<18$ years), the working-age adults (18-64 years) and the elderly (65+ years).

R 3.2 environment for statistical computing was used for data editing and descriptive analyses. The multi-level modelling procedures xtreg and xtlogit using Stata (StataCorp. 2013. Stata Statistical Software: Release 13. College Station, TX: StataCorp LP) were used to study the differences in the odds of being examined or being in need of treatment between age groups. Possible changes in these odds over time were also studied (Table 2). Multi-level modelling was also used to study the differences in examination intervals between the age groups, and possible changes in examination intervals over time (Table 4). We report both random effects and fixed effects coefficients. A random effects coefficient is a weighted average of the between and within individual factors; that is, it uses the variation between individuals as well as the variation within individuals over time. The fixed effects coefficient considers only the variation 
within individuals over time and indicates the magnitude of change in the outcome measure within the same individuals, provided that there are changes in the predictor variables.

\section{Results}

From 2001 to 2013, the number of visitors to the PDS units increased by $39.3 \%$ (Table 1). Among the visitors, the proportion of children and adolescents decreased by $0.4 \%$, the proportion of the working aged increased by $55.5 \%$ and that of the elderly by $506.1 \%$. In 2001, the young made up the biggest patient group (51.5\%), the working-aged the second biggest (45.7\%) and the elderly the smallest $(2.8 \%)$. In 2013, the working aged had become the biggest group (51.0\%) followed by the young (36.8\%) and the elderly (12.2\%).

The numbers and proportions of persons examined fluctuated during the study period (Table 1). Of all visitors during the 13 years, $80.7 \%$ had had at least one examination. Almost all (96.6\%) of the young, $71.2 \%$, of the working aged, and $63.2 \%$ of the elderly had been examined.

As Table 2 shows, compared with the elderly and the working aged, children had five times higher odds to be examined ( $\mathrm{OR}=4.97,95 \% \mathrm{CI} 4.89-5.05)$. The difference between the working aged and the elderly $(\mathrm{OR}=1.09$, 95\% CI 1.08-1.12) was negligible. Among the young, the odds of being examined decreased slightly over time ( $\mathrm{OR}=0.75$ years ( 9 months) per 5 years). A similar trend was seen among the working aged adults $(\mathrm{OR}=0.69)$ but not among the elderly $(\mathrm{OR}=1.04)$. The decreasing trend among the young was stronger $(\mathrm{OR}=0.48$ years $(6$ months) per 5 years) within individual analysis, e.g. when the same visiting individuals were followed repeatedly. A similar but much weaker trend could be detected among adults and the elderly.

A smaller number of visitors (183 children, 6727 working aged adults and 1805 elderly) had not been examined although they had visited the PDS at least in three separate years.

Compared with the elderly, children had lower odds $(\mathrm{OR}=0.31)$ and the working aged much higher odds $(\mathrm{OR}=1.72)$ to be in need of treatment (Table 2). On average, $37.4 \%$ of the examined children and adolescents, $73.1 \%$ of the working aged and $63.1 \%$ of the elderly were considered to be in need of basic treatment. A weak decreasing trend in the odds of being in need for treatment was detected, in all three age groups during the study period. Fixed and random effects were similar among both adult groups. When the same children and adolescents were followed over time (fixed effects) an increasing trend towards need for treatment was observed $(\mathrm{OR}=2.21)$, indicating that patients at risk were more often examined (Table 2).
Most examination intervals in the young and elderly (65.2-77.0\%) were 1 year or less, but only half (49.5\%) of those in the working age group had such a short interval. For them, examination intervals of three or more years were not unusual (21.2\%; Table 3$)$.

Multilevel analysis (Table 4) confirmed that, on average, children had the shortest examination intervals (reference) and those of working age the longest intervals ( 0.5 years, 6 months longer). The elderly had an interval between these two groups ( 0.16 years, about 1.9 months longer than the young). Over time, the examination intervals increased slightly in all age groups. The largest trend, 0.16 years ( 1.9 months) per 5 years, was found for the children. When the same regularly visiting individuals were followed (fixed effects), the examination intervals increased more over time than when all patients were included (random effects). In all age groups, the change in visiting intervals over time was close to zero (Table 4).

\section{Discussion}

Five PDS units using a special patient database system were chosen for this study. The data were collected from each PDS unit's database backup by the same expert using the same script. Recording of data is mandatory and in addition, part of each dentist's salary is based on treatment measures provided. The quality of data from the PDS records has been considered reliable [14]. Unfortunately, only simple clinical indicators of treatment need $(\mathrm{D}+\mathrm{d}$ and $\mathrm{CPI})$ were available. Thus, the treatment needs are likely to be underestimated, especially in adults.

During the 13-year period, the population in the five PDS units' up-take areas increased by $15.2 \%$; the young by $9.6 \%$, the working aged by $12.1 \%$ and the elderly by $31.6 \%$ [12]. Throughout the study period, the annual coverage (proportion of the population that attended the PDS) of children and adolescents was high, around $75 \%$. The coverage of working aged adults increased from 20 to $28 \%$ and that of the elderly from 5 to $22 \%$. These figures are similar to national figures and indicate that the selected PDS-units are not outliers among the Finnish PDS units [10].

During the study period, the PDS changed from being an oral health care provider mainly for the young to be a care provider for the whole population. This was the intention with the Oral Health Care Reform in 20012002 [15]. High numbers of older adults, often with accumulated treatment needs, came to the PDS, partly due to low patient fees [15]. This resulted in long waiting lists because the PDS had received few new resources but had a legal obligation to organise emergency dental services for all inhabitants in its uptake-area [16]. This study showed that although the older population grew 


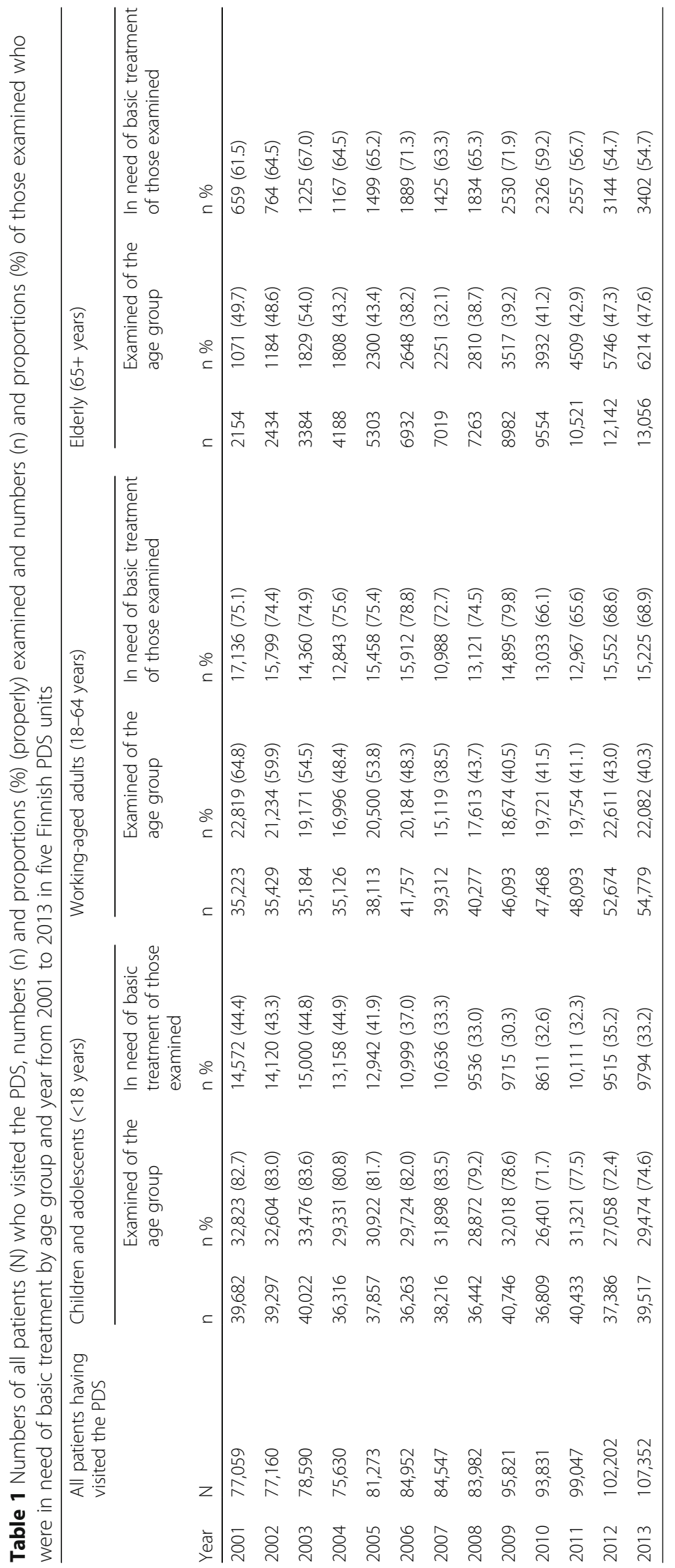


Table 2 Odds ratios of being examined and being in need of treatment after an examination by age group. All patients included that have been examined at least once

\begin{tabular}{|c|c|c|c|c|}
\hline & $\begin{array}{l}\text { Random effects; number of } \\
\text { at least once examined } \\
\text { patients/all their } \\
\text { visiting years }\end{array}$ & $\begin{array}{l}\text { Fixed effects; number of } \\
\text { patients examined at } \\
\text { least two times/their } \\
\text { pairs of examination years }\end{array}$ & $\begin{array}{l}\text { Random effects; only visits } \\
\text { with examinations/odds } \\
\text { being in need of treatment }\end{array}$ & $\begin{array}{l}\text { Fixed effects; including only } \\
\text { patients examined at least } \\
\text { two times/odds being in } \\
\text { need of treatment }\end{array}$ \\
\hline & n/observations OR (95\% Cl) & n/observations OR (95\% Cl) & n/observations OR (95\% Cl) & n/observations OR (95\% Cl) \\
\hline All age groups & $292700 / 1141446$ & $151657 / 862118$ & $235891 / 692269$ & $85905 / 411062$ \\
\hline$<18$ years & $4.97(4.89-5.05)$ & & $0.31(0.30-0.32)$ & \\
\hline 18-64 years & $1.09(1.08-1.12)$ & & $1.72(1.67-1.77)$ & \\
\hline $65+$ years & ref & & ref & \\
\hline Visiting year (per 5 years) & $0.74(0.73-0.74)$ & $0.60(0.59-0.60)$ & $0.85(0.84-0.86)$ & $1.52(1.77-2.09)$ \\
\hline Only $<18$ years & $114116 / 498986$ & $54161 / 345099$ & $110254 / 395922$ & $49646 / 263383$ \\
\hline Visiting year (per 5 years) & $0.75(0.74-0.75)$ & $0.48(0.48-0.49)$ & $0.96(0.95-0.97)$ & $2.21(2.17-2.24)$ \\
\hline Only 18-64 years & $178423 / 549528$ & $86367 / 411548$ & $126868 / 256528$ & $30309 / 108547$ \\
\hline Visiting year (per 5 years) & $0.69(0.69-0.70)$ & $0.65(0.65-0.66)$ & $0.83(0.82-0.84)$ & $0.87(0.85-0.89)$ \\
\hline Only $65+$ years & $32,139 / 92932$ & $14,056 / 64912$ & $20,281 / 39819$ & $4532 / 15416$ \\
\hline Visiting year (per 5 years) & $1.04(1.02-1.06)$ & $0.80(0.78-0.83)$ & $0.76(0.73-0.79)$ & $0.70(0.66-0.75)$ \\
\hline
\end{tabular}

All odds ratios are significant at $p<0.01$

dramatically, their share as patients in the PDS grew only from three to $12 \%$ in spite of the "free access". One explanation can be that edentulousness has been and still is common in this group; in 2000, $44 \%$ of all the 65 + year olds and, in 2011, 17\% of the 65-74 year age group and $40 \%$ of the $75+$ year olds had lost all their teeth $[8,9]$. On the other hand, when access to the PDS was restricted to the young, most dentate adults had to use private services and many of them probably have continued to visit their "own" dentists.

It was obvious from our results that the young were taken care of differently from the adults. They were five times more likely to be examined although they were three times less likely to be in need of treatment. Also the examination intervals for working aged adults were

Table 3 Number, mean values and distribution (\%) of the lengths of the visiting and examination intervals. Those persons included who had visits and examinations at least in 2 years

Number and length of the visiting interval

\begin{tabular}{|c|c|c|c|c|c|}
\hline Age group & $\mathrm{n}$ & Mean & 1 year & 2 years & $3+$ years \\
\hline (years) & & (years) & $\%$ & $\%$ & $\%$ \\
\hline $0-17$ & 393,427 & 1.3 & 74.7 & 16.5 & 4.8 \\
\hline $18-64$ & 406,542 & 1.7 & 68.4 & 16.5 & 15.1 \\
\hline $65+$ & 70,429 & 1.4 & 79.0 & 11.6 & 9.4 \\
\hline
\end{tabular}

Number and length of the examination interval

\begin{tabular}{|c|c|c|c|c|c|}
\hline Age group & $\mathrm{n}$ & Mean & 1 year & 2 years & $3+$ years \\
\hline (years) & & (years) & $\%$ & $\%$ & $\%$ \\
\hline $0-17$ & 238,585 & 1.4 & 65.2 & 28.6 & 6.2 \\
\hline $18-64$ & 85,647 & 2.0 & 49.5 & 29.3 & 21.2 \\
\hline $65+$ & 13,152 & 1.4 & 77.0 & 15.9 & 7.1 \\
\hline
\end{tabular}

on average 6 months longer and, for the elderly, 2 months longer than for the young. Furthermore, while almost all the young (97\%) had been examined, the corresponding figures for working aged adults (71\%) and for the elderly (63\%) were much lower. The young (< 18 years) have for several decades been heavily prioritised in the PDS and all care including orthodontics has been free of charge. The PDS is popular and only $1 \%$ of the young use private services [17].

The results of this study indicate that the personnel resources in the PDS are not sufficient or are inefficiently used as regards adult care. In order to transfer clinical activities from the young towards adults known to have greater treatment needs, there have been attempts to individualise and extend patients' recall intervals, starting with the children and younger adults [18]. This "thinning-out the examinations" philosophy has later been applied to other adults, too. Thus, for example, the PDS in Helsinki recommends that a dentist should examine "healthy adults" in every 4 to 5 years and visit a hygienist every 2 to 3 years [19]. However, most of the "new" patients (born before 1956) who came to the PDS in 2002 and after were not likely to have been healthy adults. The national studies in 2000 and 2011 revealed great treatment needs in the adult population, such as missing teeth needing prosthetic replacements, caries and broken fillings and not least periodontal disease of various degrees and generally bad oral hygiene especially in the low income and low education groups $[8,9]$. A recent study in the PDS of a bigger city showed that there were high numbers of middle aged and older "heavy consumers" with low socioeconomic background showing up repeatedly for lost fillings 
Table 4 The effect of age group and visiting year on the visit and examination intervals

\begin{tabular}{|c|c|c|c|c|}
\hline & $\begin{array}{l}\text { Random effects, visit interval } \\
\text { n/observations } \mathrm{B}(95 \% \mathrm{Cl})\end{array}$ & $\begin{array}{l}\text { Fixed effects, visit interval } \\
\text { n/observations B(95\% Cl) }\end{array}$ & $\begin{array}{l}\text { Random effects, exam interval } \\
\text { n/observations } B(95 \% \mathrm{Cl})\end{array}$ & $\begin{array}{l}\text { Fixed effects, exam interval } \\
\text { n/observations B(95\% Cl) }\end{array}$ \\
\hline All age groups & $190,811 / 657200$ & $190,811 / 657200$ & $128,329 / 337242$ & $128,329 / 337242$ \\
\hline$<18$ years & ref & & ref & \\
\hline $18-64$ years & $0.13(0.13-0.14)$ & & $0.50(0.49-0.51)$ & \\
\hline $65+$ years & $-0.03(-0.04--0.03)$ & & $0.16(0.15-0.18)$ & \\
\hline Visiting year (per 5 years) & $0.02(0.01-0.02)$ & $0.01(0.00-0.01)$ & $0.13(0.12-0.13)$ & $0.20(0.19-0.21)$ \\
\hline Only $<18$ years & $78,560 / 289819$ & $78,560 / 289819$ & $72,812 / 214232$ & $72,812 / 214232$ \\
\hline Visiting year (per 5 years) & $0.02(0.02-0.03)$ & $-0.03(-0.04-0.03)$ & $0.16(0.15-0.16)$ & $0.19(0.19-0.20)$ \\
\hline Only 18-64 years & $109,527 / 307174$ & $109,527 / 307174$ & $55,607 / 103482$ & $55,607 / 103482$ \\
\hline Visiting year (per 5 years) & $-0.02(-0.02-0.01)$ & $0.01(0.01-0.02)$ & $0.07(0.06-0.08)$ & $0.15(0.13-0.16)$ \\
\hline Only $65+$ years & $20,691 / 60207$ & $20,691 / 60207$ & $10,001 / 19528$ & $10,001 / 19528$ \\
\hline Visiting year (per 5 years) & $0.05(0.03-0.06)$ & $0.05(0.04-0.07)$ & $0.07(0.05-0.10)$ & $0.20(0.16-0.24)$ \\
\hline
\end{tabular}

Patients with at least two visits or examinations included. Second visit in 2005 or later. Only observations with an interval of 4 or less years included Visiting year is a continuous and age group a categorical predictor All coefficients significant at $p<0.01$ level

$B=$ change in years per one unit change in the predictor

and other semi-acute treatment and they were not offered examinations nor regular treatment [20, 21]. Most PDS units recall the young only, in contrast to the private sector, which uses recall as one of its most important marketing tools [22]. In the PDS, adults are advised to make new appointments after a given time period and are then put on the waiting list again [23]. This happens partly due to the Care Guarantee legislation from 2005, which stipulates that emergency services have to be given within 3 days and non-urgent care has to be started within 6 months for all those asking for treatment in the PDS. Postponing further treatment sessions and old (adult) patients' new treatment episodes has become a way to cope with the legal requirements. It has also been suggested that many PDS dentists used to treating younger patients do not feel competent to treat older adults with more complex treatment needs [24] and our study indicates that older adults probably still have "invisible" access barriers in the PDS. Thus, the findings reflect national special features in the care provision system, such as contradictory incentives between public and private care providers in adult dental care, the lack of national steering and vague local leadership [25]. As a result, the PDS continues to prioritise the young and is not successful in meeting the internationally recommended examination intervals for adults. This might be one reason for the persisting oral health inequalities in Finland. During the current economic recession, acquiring resources for public oral health care is challenging. As an alternative, the PDS should probably reorganise its treatment processes, review the division of labour and the remuneration system and put more effort into improving adult patients' oral hygiene and home care and into continuing education for its own staff.

\section{Conclusions}

Most young patients in the PDS are recalled regularly and in line with best practice guidelines. Due to lack of a recall system, adults' examination intervals had increased and, in spite of much greater treatment needs, were longer than the recommended in other countries. However, visiting intervals for all age groups were shorter, around 1 year and they did not increase. This suggests that the examination intervals for adults are too long, especially in relation to their treatment needs.

\section{Acknowledgements}

We are grateful for the PDS units that offered their data for our use. We would also like to thank Jari Moisanen, Miikka Ristkari and Esko Ristkari from In Net Ltd. for their valuable help in gathering the material for this study.

Funding

The study was supported by a Research Grant from the Social Insurance Institute Kela.

\section{Availability of data and materials}

The data that support the findings of this study are available from the National Institute for Health and Welfare ( $\mathrm{THL}$ ) but restrictions apply to the availability of these data, which were used under license for the current study, and are thus not publicly available. Data are, however, available from the authors upon reasonable request and with permission of the National Institute for Health and Welfare $(\mathrm{THL})$ as well as the participating communities.

\section{Authors' contributions}

$J \mathrm{~L}$ and EW planned and designed the study. $J \mathrm{~L}$ organized the practicalities and the data collection. $J$ and $K J$ analyzed the data. EW helped to interpret the results. $J$ and EW drafted the manuscript. All authors read and approved the final paper.

\section{Ethics approval and consent to participate}

Ethical Committee approval for this study was not necessary according to Finnish law and the obligations of the National Institute for Health and Welfare (THL). This study was considered to be routine work at THL and the Department's Director approved the data collection.

Consent for publication

Not applicable. 


\section{Competing interests}

The authors declare that they have no competing interests.

\section{Publisher's Note}

Springer Nature remains neutral with regard to jurisdictional claims in published maps and institutional affiliations.

\section{Author details}

${ }^{1}$ Public Dental Service Lohja, Helsinki, Finland. ${ }^{2}$ National Institute for Health and Welfare (THL), Helsinki, Finland. Institute of Clinical Dentistry, Arctic University of Norway, Tromsø, Norway.

Received: 22 December 2016 Accepted: 20 November 2017 Published online: 28 November 2017

\section{References}

1. Riley P, Worthington HV, Clarkson JE, Beirne PV. Recall intervals for oral health in primary care patients. Cochrane Database Syst Rev. 2013; doi:10.1002/14651858.CD004346.pub4

2. NICE, the National Collaborating Centre for Acute and Chronic Conditions. Dental recall - Recall interval between routine dental examinations. Clinical guideline [CG 19]. 2004. http://guidance.nice.org.uk/CG19. Accessed 2016 Nov 26

3. American Dental Association (ADA). How Often Should a Person Go to the Dentist? Questions About Going to the Dentist - Mouth Healthy. 2016. http://www.mouthhealthy.org/en/dental-care-concerns/questions-aboutgoing-to-the-dentist. Accessed 2016 Nov 26.

4. Irish Dental Association (IDA). How often should I visit my dentist? FAQs. 2016. www.dentist.ie/your-oral-health/faqs.264.html. Accessed 2016 Nov 26.

5. Colgate Oral and Dental Health Resource Center. How often should you go to the dentist? 2016. http://www.colgate.com.my/app/CP/MY/OC/ Information/Articles/Oral-and-Dental-Health-Basics/Checkups-and-DentalProcedures/The-Dental-Visit/article/Dental-Visits-The-Dentist-Visit-and-Whatto-Expect.cvsp. Accessed 2016 Nov 26

6. Niiranen T, Widström E, Niskanen T. Oral health care reform in Finland aiming to reduce inequity in care provision. BMC Oral Health. 2008;28(8):39. doi:10.1186/1472-6831-8-3.

7. Aromaa A, Heliovaara M, Impivaara O, Knekt P, Maatela J. The execution of the mini-Finland health survey. 1989, Helsinki and Turku: the Social Insurance Institution 1989;88;185-199.

8. Suominen-Taipale, L, Nordblad A, Vehkalahti M, Aromaa A, eds. Oral health in the Finnish adult population. Health 2000 survey. Publications of the National Public Health Institute (KTL) B25. Helsinki: Hakapaino Oy; 2008.

9. Koskinen S, Lundqvist A, Ristiluoma N, eds. Terveys, toimintakyky ja hyvinvointi Suomessa 2011 In: THL Raportti 68. Tampere: Juvenes Print Suomen yliopistopaino Oy; 2012. (Health, functional capacity and welfare in Finland in 2011, English summary.)

10. SOTKA, Municipal Database for Social and Health Care in Finland. THL. http://uusi.sotkanet.fi/portal/page/portal/etusivu. Accessed 30 Jan 2016.

11. Korhonen H. Tietojärjestelmät suun terveydenhuollon ohjauksessa ja johtamisessa Suomessa 1972-2001. Thesis. Kuopio: University of Kuopio; 2005. (Information systems in the steering and management of oral health care in Finland 1972-2001, English summary.).

12. Statistics Finland. Population structure. http://www.stat.fi/til/vaerak/index html. Accessed 30 Jan 2016.

13. Oral health surveys: basic methods - 5th edition. World health organization. Geneve: WHO press; 2013.

14. Hausen H, Kärkkäinen S, Seppä L. Caries data collected from public health records compared with data based on examinations by trained examiners. Caries Res. 2001:35:360-5.

15. Widström E, Seppälä T. Willingness and ability to pay for unexpected dental expenses by Finnish adults. BMC Oral Health. 2012;12:35. doi:10.1186/14726831-12-35.

16. Terveydenhuoltolaki 30.12.2010/1326. http://www.finlex.fi/fi/laki/ajantasa/ 2010/20101326. Accessed 30 Jan 2016. (Law of Health Services, In Finnish.)

17. Valtiovarainministeriö. Peruspalvelujen tila - raportti 2014. Kunnallistalouden ja - hallinnon neuvottelukunta. Valtiovarainministeriön julkaisuja 9. Helsinki: Suomen Yliopistopaino OY; 2014. (Ministry of Finance: Report on Basic Public Services 2014, English summary.).

18. Lahti SM, Hausen HW, Widström E, Eerola A. Intervals for oral health examinations among Finnish children and adolescents: recommendations for the future. Int Dent J. 2001;51:57-61.
19. Helsinki social and health care. Hoitoonpääsy ja kutsukäytännöt. http://www. hel.fi/static/sote/tiedotteet/asiakkaille/Hoitoonpaasy_ja_kutsukaytannot vauvasta_vaariin.pdf. Accessed 26 Nov 2016. (Access to treatment and recall practices, In Finnish.)

20. Nihtilä A, Widström E, Elonheimo O. Heavy consumption of dental services among Finnish adults. Community Dent Health. 2010;27(4):227-32.

21. Nihtilä A-M, Widström E, Elonheimo O. Adult heavy and low users of dental services: treatment provided. Swed Dent J. 2016;40(1):21-32.

22. Mikkola H, Vesivalo A, Jauhiainen S, Widström E. An Outlook of Dental Practices - Drivers, Barriers and Scenarios. Liiketaloudellinen aikakauskirja (The Finnish J Business Economics). 2007:56(2):167-192.

23. Widström E, Tiira H, Alestalo P, Pietilä I. Terveyskeskushammaslääkärit uuden edessä. Suomen Hammaslääkäril. 2010;27(8):28-33. (Public dentists' experiences of a major oral health care reform, English Summary.)

24. Widström E, Kemppinen M, Linden J. Johtavat hammaslääkärit uskovat tehostamismahdollisuuksiin sotessa. Suomen Hammaslääkäril. 2016;23(10): 24-29. (Chief dentists believe in increasing efficiency in the PDS in connection with the major social and health care reform in Finland, English summary.)

25. Alestalo P. Management and leadership in the public dental Service in Finland between 2003 and 2011, Thesis. Helsinki: University of Helsinki; 2015.

\section{Submit your next manuscript to BioMed Central and we will help you at every step:}

- We accept pre-submission inquiries

- Our selector tool helps you to find the most relevant journal

- We provide round the clock customer support

- Convenient online submission

- Thorough peer review

- Inclusion in PubMed and all major indexing services

- Maximum visibility for your research

Submit your manuscript at www.biomedcentral.com/submit
Biomed Central 